\title{
Employees' Feedback: Critical Success Factors in Managing Compliance Efficiency in an Organisation
}

\author{
Nadya Naina Bt Rahmat ${ }^{l}$ and Professor Dr. Mohamad Sahari Bin Nordin ${ }^{2}$ \\ ${ }^{1}$ Graduate School of Management, Kulliyyah of Economics and Management Sciences, \\ International Islamic University, Malaysia, \\ ${ }^{2}$ Kulliyah of Education, International Islamic University, Malaysia
}

\begin{abstract}
There is clear a need to measure and analyse data that will guide an organization to manage compliance in the most effective manner. Despite its importance, a valid and reliable instrument, particularly one that manages employees' feedback, is hardly available. One primary aim of this study was to examine the extent to which a 4-dimension self-reported compliance, as perceived by the employees, constituted an adequate measure in terms of its reliability, convergent validity and discriminant validity. Another aim of the study was to test the measurement equivalence of the tool for male and female employees. The sample consisted of 250 employees from several private companies in Malaysia. The data was analysed using a confirmatory factor analysis on the sample' responses to 12 perception items. The study supported and extended the results of previous work on employees' feedback and perceptions towards policy and procedure compliance. The study found evidence that the instrument measures a valid and reliable multidimensional construct, and it is gender-invariant using Confirmatory Factor Analysis (CFA). Thus, the instrument is a useful tool for business leaders to facilitate their efforts in ensuring that day-to-day operations meet their business objectives as well as the necessary regulatory requirements.
\end{abstract}

Key words: Compliance management, employees ' participation, confirmatory factor analysis, policy and procedures

\section{INTRODUCTION}

Business leaders in every organization, regardless of industry face a certain degree of risk in dealing with dayto-day operational activities. According to Arias.A [1], understanding and managing compliance is key for ensuring effective conservation, nevertheless crucial concepts and tools are scattered in a wide array of literature, Proactive business leaders usually adopted various methods in managing uncertainty in business to avoid fines, penalties, and damage to reputation. Hence, to control operations effectively, each organisation in various industries has developed policies and procedures as essential tools of defense where policies and procedure guide employees, suppliers/vendors, and interested parties to manage uncertainty in their operations. It is essential for business leaders to have a set of documents designed to guide and involve their personnel directly or indirectly in decision making as stated by Ryzhakina, T., Koroleva, N., \& Makasheva, N [2]. These documents tell who, when, what, where and how to execute duties to comply with industrial-specific obligations. As such, employees may take necessary action within the organisation and its context.

It is important for the employer and employees to embed these in their daily activities and carry out their tasks based on policy and procedures to produce high-quality products and services, meet customers' needs and expectations, deliver good corporate governance and enhance long-term sustainability. By developing policy and appropriate procedures, an organisation is relying on the best-practice methods, processes and standardised work methods that are constantly reviewed and improved. Therefore, having adequate documented policy and procedures which are straightforward, detailed step-by-step and clearly understood by employees may protect the organisation against the loss of valuable information. Therefore, the established policy and procedures should be communicated at all levels of employees to seek stability and control toward compliance management. Quinn, R. E., \& Rohrbaugh, J. [3] point out that an organization with strong rule orientation would invest a significant amount of time developing and implementing carefully designed

Corresponding Author: Nadya Naina Bt Rahmat, Kulliyyah of Economics and Management Sciences, International Islamic University, Malaysia, nadyanaina@yahoo.com 
policies and would devote a significant amount of effort on training employees. A rule-oriented organization culture signals strong expectation via multiple channels, such as internal communication and formal training programs for employees (including peers, superiors, and subordinates) to ensure compliance with the rules and policies. Thus, apart from diffusing new knowledge and developing new skills, it is very important for trainers to introduce trainees to the appropriate new job-related behavioural norms, a combination (knowledge, skills and behaviour) that will allow the desired training results to be achieved Nda, M. M., \& Fard, R. Y. [4] training and development is an instrument that aid human capital in exploring their dexterity. Therefore training and development is vital to the productivity of organization's workforce.

On the other hand, most of the organisations took proactive steps by obtaining ISO certification from the accreditation body for internal control mechanisms in managing compliance. According to Neyestani, B., \& Juanzon, J. B. P. [5]. ISO has been adopted by different organisations in all over the world. Several empirical studies revealed the importance of this quality management tool for improving continuously performance within the organizations in order to satisfy customer's needs and promote competitiveness in the market. According to Pambreni, Y., Khatibi, A., Azam, S., \& Tham, J. [6], recognizing TQM values with four critical elements of TQM that are utilized in this study, i.e. customer focus, continuous improvement, strategically based, and total employee involvement. The research results sustain and enrich theories about how TQM affects organization performance improvement. There were various business functions of ISO standard offered, namely; ISO9001 (Quality Management System), ISO14001 (Environment Management System), ISO45001 (Occupational Safety and Health Management System), ISO5001 (Energy Management System), and many more. According to Alexander, A., Kumar, M., \& Walker, H. [7], the actions of employees can thus become motivated by working to the Performance Management Metric and the structures it creates, rather than to the traditional goals or objectives of the organisation. According to Pal, K., \& Bansal, H. [8] in the study focused on the management concepts and organization behavior as one of the indicator to avoid creation of wrong behaviour and mind-sets in an organisation where employees overperform or under-perform to meet the targets against the assigned metrics set by management. According to Terlaak, A., \& King, A. A [9], mentioned in the article, the positive effects from ISO 9000 quality managements system to an organization. Therefore, the subscription to ISO standard can assist the management mainly focuses on the adequacy of the policies and procedures of the company to support the business operation effectively. As suggested by El Kharbili, M., Stein, S., \& Pulvermüller, E. [10], policies can also be expressed using formalisms such as rules. Rules are one classical and very intuitive way of expressing/implementing policies. It provides a series of guidelines on how to establish a system to manage the processes that affect its products and services. It was first developed in 1987 and aimed at promoting the quality of services and goods provided by different sectors of the industry. Since its establishment, the International Organization for Standardization, it has been gradually adopted by most all industries worldwide.

Certainly, compliance also relates to the mis-behaviour of an individual as stated by Analoui, F., \& Kakabadse, A. [11], "non-compliant behavior", Fritz, J.[12], "unconventional practices at work", and several scholars have emphasized the effect factors have on employees' misconduct where undesired outcome of the compliance framework established in an organisation. According to Geddes, B. H. [13], a firm and a rigorous ethics program are essential in business today. Consumers demand that the companies that they do business with be ethical. Compliance and integrity based ethics programs are the leading pragmatic approaches to ethics used in today's business environment. It also can refer to the huge financial scandals which occurred in major companies such as Enron, Worldcom, Satyam, and more recently 1MDB. This was discussed much details as cited by Agyei-Mensah, B. K. [14] in term of corporate governance. The implementation of compliance management is the main priority in an organisation to prevent major non-compliance towards regulatory requirements. Today, compliance audit has become more exacting to ensure the internal controls of an organisation are stringent and follow the policies and procedures established to adhere to the set of requirements. According to Arena, M., \& Azzone, G. [15], effectiveness of internal auditing is influenced by: (1) the characteristics of the internal audit team, (2) the audit processes and activities, and (3) the organizational links. During the audit exercise, the organisation shall provide all relevant documents requested as proof of compliance with the laws and regulations.

\section{RESEARCH PROBLEM}

This study is to address the gap in the existing research on compliance management in an organisation where no profound study has been conducted to examine employees' self-participation, system and facilities, management team's commitment and adequacy of training collectively in practicing compliance based on established policy and procedures. Thus, the compliance instrument was developed to measure employees' feedback on the established policies and procedures based on their self-participation, system and facilities, the commitment and leadership of the management's team and the adequacy of training in an organisation in all circumstances. There is one study documented by Kibalirwandi, M. M., Akena, D. H., \& Mwesigye, A. R. [16] on employees' policy implementation compliance scale on quality assurance policy. Still, not much has been reported about the validity and reliability of the measurement of self-reported compliance. 


\section{COMPLIANCE AND KEY CONCEPTS}

It is important to have indepth understanding of the compliance framework for planning, controlling, and managing employees' compliance collectively in achieving effectiveness of its implementation in an organisation. An overall framework to support the business leaders or line managers based on 4-dimensions is explained as follows:

\section{Dimension 1: Employees Self-Participation}

Dimension 1 focused on awareness of employees toward policies and procedures established in an organisation and their willingness to participate by contributing ideas, understanding and adherence to the set policy and procedures. It also covers their involvement in compliance initiatives, attending training organised by their organisation and being responsible enough to report noncompliance activities to the management's team. According to Bacud, S. A. D. [17], this dimension is critical to measure and is cited in the Henri Fayol principle theory that an environment should be created in the organization which will induce people to contribute to each other's efforts in such a way that the combined effort of all together promotes the achievement of the overall objectives of enterprise.

Hence, Bonau, S. [18] analysed the level of employee commitment using twelve variables which represent employees' attitudes towards the job, the workplace, and working at the workplace, including satisfaction with management. Then, Bonau, S. [19] stated that human resource measures which encourage employee involvement, and those that foster the development of the employee's skills. Intellectual Quality was found to potentially have a negative relation with organisational commitment.

\section{Dimension 2: System and Facilities}

Dimension 2 focused on the adequacy of the system and facilities relating to the preparing and organising of the policy and procedures documents for compliance management in the organisation to be accessed by employees. The policy and procedures should be clearly stated, including their clarity, comprehensiveness, flowchart that tells what, who, when, where and how specific duties are to be carried out to meet the compliance's requirements. It also comprises the facilities provided by an organisation either through softcopy or hardcopy, since the policy and procedures should be easily accessible by employees at all times for their reference. Peter F Drucker [20] in the theory has said that an organization's structure is a systematic combination of people, functions and physical facilities. It has to be designed primarily for determining the channel of communication and flow of authority and responsibility.

Dimension 3: Management Team's Commitment Dimension 3 focused on a group of people who had the capability to influence and the appropriate authority to make decisions toward compliance management in the organisation by demonstrating their commitment and leadership. Javed, S. [21] emphasized that there is a common agreement as to the importance of leadership by management in implementing quality management. Top management is mandatory to all strategy and action plans. This dimension ensures the accountability of management's team in terms of their decision making, recognition, guidance, and consultation towards employees' compliance management with reference to established policy and procedures. It also extended to the capability of the appointed internal auditor in providing adequate assessment on compliance management in the organisation. According to Cederquist, J. G., Corin, R., Dekker, M. A., Etalle, S., den Hartog, J. I., \& Lenzini, G. [22], auditors can observe critical actions. Hence there must be a sufficiently comprehensive audit trail, which cannot be forged or bypassed, containing the relevant details about the actions and the identity of the users executing them Hence, management's team shall empowered internal auditor to carry out their duties and referring to Davis, R. C. [23] stated that; "Management is the function of executive leadership anywhere." It recognizes the quality of leadership as a critical factor in management success. It also recognizes the role of individual psychology and group behaviour in organizational effectiveness.

\section{Dimension 4: Compliance Training}

Lastly, dimension 4 which it focused on the availability and adequacy of training in the organisation for employees in terms of planning, frequency, coverage and intention to improve knowledge and understanding to meet the requirements of compliance management. According to Diamantidis, A. D., \& Chatzoglou, P. D. [24], the design of a training programme has the strongest impact on posttraining job performance, along with trainees' self-efficacy and post-training behaviour. According to Susomrith, P., Coetzer, A., \& Ampofo, E [25], it is reasonable to agree that employees who participated in more training and development events were more likely to enact innovative behaviours, while affective commitment mediated the positive relationship between number of training and development events attended and innovative behaviours. The training conducted related to policy, procedures and compliance related activities. According to Frederick W. Taylor's [26] theory an organisation may use job descriptions to select employees, set up formal training systems, and establish optimal work standards to follow.

Based on extant literature of compliance, we hypothesized that:

H1 Employees' responses towards an organization's compliance practices consist of 4 interrelated factors, which are employees' participation, system and facilities, management team commitment, and compliance training.

H2 The 4-factor compliance solution is psychometrically sound in terms of reliability, convergent validity, and discriminant validity. 
Nadya Naina \& Mohamad Sahari/ International Journal of Business and Management, 4(6) 2020, Pages: 09-16

H3 The measurement of employees' feedback on compliance practices is applicable, i.e. invariant across gender.

\section{METHODOLOGY}

Sample

A total of 250 respondents who work in construction, financial services, accreditation, education and government in Malaysia. They completed a psychometric scale survey which consists of a 5-point scale and the degree to which they strongly disagreed to strongly agreed. A self-reported questionnaire was developed based on 4 dimensions namely employees' selfparticipation, system and facilities, management's team commitment, and compliance training. This scale asked the respondents their agreement and disagreement with each questionnaire from (1) Strongly Disagree, (2) Disagree, (3) Neutral, (4) Agree, and (5) Strongly Agree. This survey was conducted on two platforms; face-to-face and online. Additional information such as gender, years of experience, position/designation and industry/sector was also included in the survey.

This is made reference and guidance as stated in Crede, M., \& Harms, P. [27] which can reduce the degree to which readers are exposed to disconfirming evidence. The sample size was sufficient to address the research objectives and adequately fulfil the requirements for running a confirmatory of factor analysis.

\section{Compliance Instrument}

The compliance instrument comprises 4 dimensions as follows:

\begin{tabular}{|c|c|c|}
\hline $\begin{array}{l}\text { Dimensions } \\
\text { (D) }\end{array}$ & $\begin{array}{l}\text { Areas of } \\
\text { Concern }\end{array}$ & Responsibility \\
\hline $\begin{array}{l}\text { D1 - Self- } \\
\text { Participation }\end{array}$ & $\begin{array}{l}\text { - Active in } \\
\text { reading Policy } \\
\text { and Procedures } \\
\text { - Active in } \\
\text { contributing } \\
\text { ideas in work } \\
\text { processes } \\
\text { - Awareness of } \\
\text { Policy and } \\
\text { Procedures } \\
\text { - Refers to Policy } \\
\text { and Procedures } \\
\text { to carry out } \\
\text { duties } \\
\text { - Involved in } \\
\text { compliance } \\
\text { activities } \\
\text { - Reports non- } \\
\text { compliance } \\
\text { activities } \\
\text { - Attends } \\
\text { compliance } \\
\text { training }\end{array}$ & Employees \\
\hline
\end{tabular}

\begin{tabular}{|c|c|c|}
\hline $\begin{array}{l}\text { D2- System } \\
\text { and Facilities }\end{array}$ & $\begin{array}{l}\text { - Easy access to } \\
\text { Policy and } \\
\text { Procedures } \\
\text { - Easy to } \\
\text { understand } \\
\text { Policy and } \\
\text { Procedures } \\
\text { - Clear and } \\
\text { straightforward } \\
\text { Policy and } \\
\text { Procedures } \\
\text { - Policy and } \\
\text { Procedures are } \\
\text { available to } \\
\text { everyone } \\
\text { - Policy and } \\
\text { Procedures } \\
\text { distributed } \\
\text { efficiently } \\
\text { - Penalty and } \\
\text { rewarding } \\
\text { system are } \\
\text { established for } \\
\text { control } \\
\text { measures }\end{array}$ & $\begin{array}{l}\text { Management's } \\
\text { Team }\end{array}$ \\
\hline $\begin{array}{l}\text { D3- } \\
\text { Management's } \\
\text { Team }\end{array}$ & $\begin{array}{l}\text { - Leadership } \\
\text { - Commitment } \\
\text { - Decision } \\
\text { Making } \\
\text { - Guidance } \\
\text { - Consultation } \\
\text { - Rewarding } \\
\text { - Sharing } \\
\text { Business's } \\
\text { Goals } \\
\end{array}$ & $\begin{array}{l}\text { Management's } \\
\text { Team }\end{array}$ \\
\hline $\begin{array}{l}\text { D4- } \\
\text { Compliance } \\
\text { Training }\end{array}$ & $\begin{array}{l}\text { - Training } \\
\text { coverage } \\
\text { - Sufficient and } \\
\text { meets training } \\
\text { objectives } \\
\text { - Planning and } \\
\text { shared with all } \\
\text { employees } \\
\text { - Training } \\
\text { Frequency } \\
\text { - Post training } \\
\text { feedback }\end{array}$ & $\begin{array}{l}\text { Employees' } \\
\text { and } \\
\text { Management's } \\
\text { Team }\end{array}$ \\
\hline
\end{tabular}

Procedure of Data Analysis

The study first tested two measurement models of employees' feedback on compliance practices: a onefactor model and a four-factor model. The four-factor model was tested to establish the adequacy of the hypothesized measurement model, while the one-factor confirmatory factor analysis aimed to validate the multidimensional nature of the construct. The expected multidimensionality of the compliance feedback measure is at stake if the one-factor model yielded better fit. A superior one-factor model would challenge the reliability of the multidimensionality of the measure. On the other hand, an ill-fitting one-factor CFA of instrument suggests the lack of threats to multidimensionality. Additionally, the testing of the two models aimed to address the issue of 
common method bias, an apparent effect of using a single questionnaire to collect and analyze self-reported data in details is referring to Brown, T. A. [28] where the Detailed, worked-through examples drawn from psychology, management , and sociology studies illustrate the procedures, pitfalls, and extensions of CFA methodology

A CFA using the AMOS (version 24), Byrne, B. M. [29], model-fitting program was used to evaluate the two measurement models of employees' feedback on compliance practices. Firstly, the models were estimated using the covariance matrix of the data; the maximum likelihood estimation procedure was adopted to produce the estimates. Preliminary analysis indicated that the assumption of univariate normality was tenable. Secondly, the adequacy of each model was assessed using the widely used standards for a good-fit CFA, which are: (i) consistency of the measurement model with the data, and (ii) reasonableness of the parameter estimates. The analysis used the relative chi-square $\left(\chi^{2} / \mathrm{df}\right)$, CFI (comparative fit index), and RMSEA (root mean square error of approximation) as the fit indexes (23-24).

Thirdly, the study examined the psychometric properties of the model by assessing the components of construct validity, which are convergent validity and discriminant validity. The internal consistency of each sub-construct was measured through composite reliability and Cronbach's alpha. Finally, a multigroup analysis was conducted to ascertain that the instrument was genderinvariant. To test a gender-invariant measure, a two-step simultaneous analysis on both the male $(\mathrm{n} 1=139)$ and female ( $\mathrm{n} 2=111$ ) groups was conducted, first without constraining the factor loadings, intercepts, residual errors; the results derived a baseline Chi-square value. Second, all loadings were constrained to be equal in the two samples Wu, A. D., Zhen, L., \& Zumbo, B. D. [30].

\section{RESULT ANALYSES AND DISCUSSIONS}

Table 1 shows the descriptive statistics of the items included in the confirmatory analysis. The maximum possible score for each item is 5 ; the mean score of all items distributed above the hypothetical mean of 2.5. The value of each Cronbach's alpha, which is the reliability index of the responses to the related items, was reasonably high. The minimum value of the internal consistency index was .82, and it exceeded the critical cut-score of .70 for a reliable measure.

Table 1 shows the Dimensions and Statistics of Policy Compliance Practices

Table 1: Dimensions and Statistics of Policy Compliance Practices

\begin{tabular}{|c|c|c|c|c|}
\hline Code & Compliance Component/Indicator & Mean & SD & Alpha \\
\hline A 1 & I am active in reading Company’s Policy and Procedures & 3.85 & 0.80 & \multirow[t]{3}{*}{0.89} \\
\hline A2 & I understood the Company's Policy and Procedure requirement & 4.03 & 0.70 & \\
\hline A3 & $\begin{array}{l}\text { I refer to the Company's Policy and Procedure to carry out my } \\
\text { job duties }\end{array}$ & 4.01 & 0.70 & \\
\hline B 1 & $\begin{array}{l}\text { The Company's Policy and Procedure are made available to } \\
\text { everyone }\end{array}$ & 4.59 & 0.79 & \multirow[t]{3}{*}{0.9} \\
\hline B2 & $\begin{array}{l}\text { The Company's Policy and Procedures are distributed/circulated } \\
\text { efficient }\end{array}$ & 4.56 & 0.75 & \\
\hline B3 & $\begin{array}{l}\text { The contents/language use in the Company's Policy and } \\
\text { Procedures are clear and straightforward }\end{array}$ & 4.60 & 0.69 & \\
\hline $\mathrm{C} 1$ & $\begin{array}{l}\text { Management team demonstrates their leadership and } \\
\text { commitment toward Company's Policy and Procedures }\end{array}$ & 3.40 & 0.83 & \multirow[t]{3}{*}{0.82} \\
\hline $\mathrm{C} 2$ & $\begin{array}{l}\text { Management team makes decision based on Company's Policy } \\
\text { and Procedure }\end{array}$ & 3.24 & 0.81 & \\
\hline C3 & $\begin{array}{l}\text { Management team educates employees on the impact for non- } \\
\text { complying with the Company's Policy and Procedure }\end{array}$ & 3.12 & 0.87 & \\
\hline D1 & Training is conducted to all employees & 4.02 & 0.85 & \multirow[t]{3}{*}{0.82} \\
\hline D2 & Training's content is sufficient and meet the training objective & 4.22 & 0.73 & \\
\hline D3 & Training programme plan is shared to all employees & 4.10 & 0.83 & \\
\hline
\end{tabular}

Validity of Multidimensional Policy Compliance Construct

To test the validity of the policy compliance feedback instrument, 2 confirmatory factor analyses (CFAs) were applied on the data. The results of the first CFA indicated that the one-factor structure was inadequate to represent the data. The model produced poor fit statistics; $\chi 2 / \mathrm{df}=$ $20.6, \mathrm{CFI}=.395 ; \mathrm{RMSEA}=.281$. The model did meet the standards deemed important for a good-fit measure. Put differently, the results revealed that the data did not support the possibility of a one factor instrument to measure the practice of policy compliance as perceived by the employees. Consequently, the results of the first CFA did not indicate any substantive threats of common method bias. Figure 1 shows Results of the Hypothesized Measure of Policy Compliance Feedback Measure. 
Figure 1: Results of the Hypothesized Measure of Policy Compliance Measure

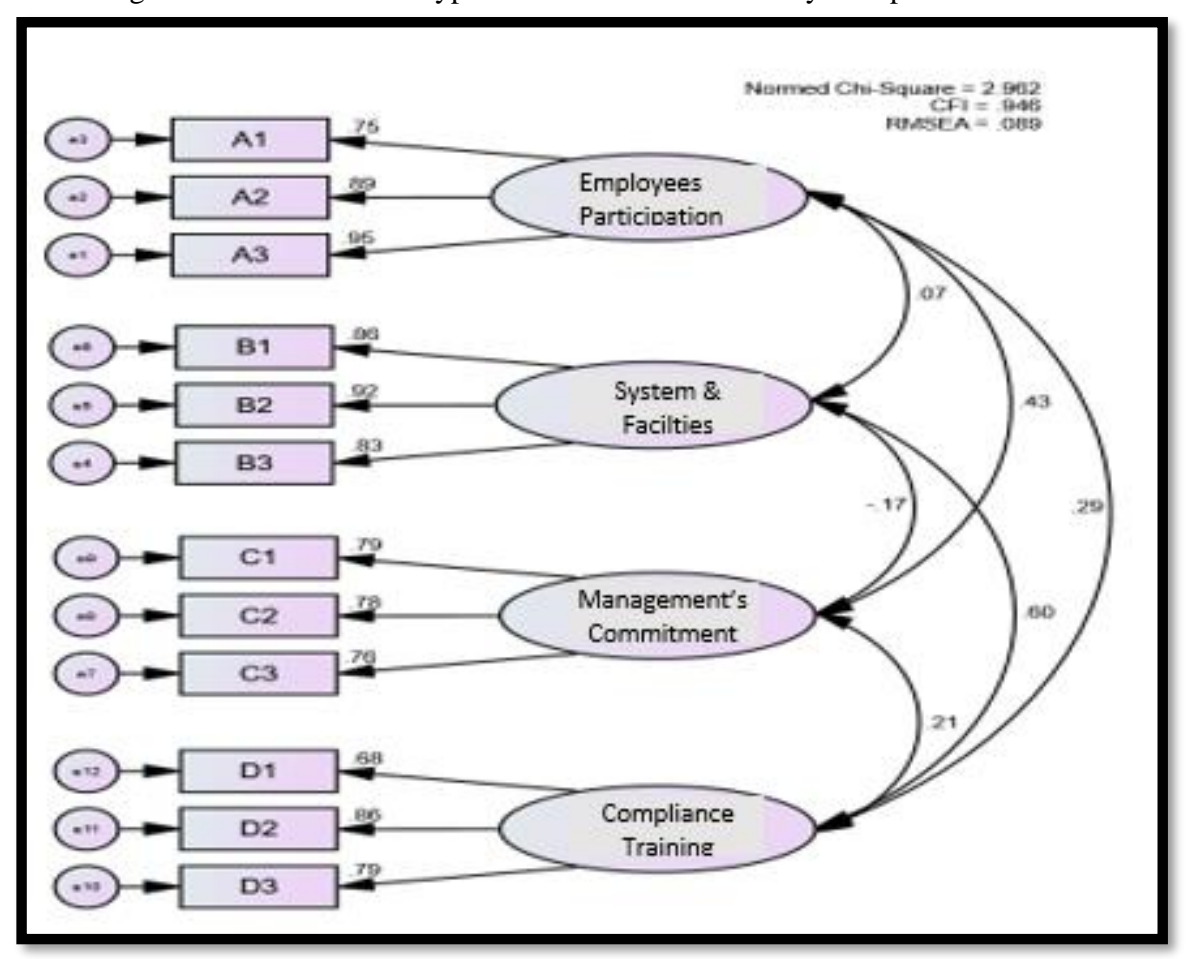

The results of the second CFA are summarized in the path diagram (Figure 1). As expected, the CFA provided evidence supporting the validity of the four-factor compliance practice. The measurement model fitted the variance-covariance matric; $\chi 2 / \mathrm{df}=2.96 ; \mathrm{CFI}=.948$; RMSEA $=.089$. All parameter estimates were substantial and statistically significant. The direction and magnitude of the factor loadings were behaving as expected, the smallest being $\lambda=.68$. The 4 components of policy compliance practices, namely, employees' participation, system and facilities, management team commitment, and policy training were somewhat correlated, with the strongest relationship of $r=.60$ between policy training and system and facilities. Hence, the results suggested that the hypothesized measure of policy compliance feedback was consistent with the data. Thus, it is reasonable to use the 4 dimensions instrument to reliably measure employees' feedback on the organization's policy compliance practices.

\section{Psychometric Properties of Policy Compliance Feedback Measure}

The results of the CFA also support the reasonableness of psychometric properties of the instrument in terms of its convergent validity and discriminant validity (Table 2). The average amount of variation (AVE) of each component was sufficiently explained by its respective indicators, and this indicates the adequacy of convergent validity of the measurement. Since the value of the of each construct was larger than the threshold of 0.5 , each component holds sufficient properties of convergent validity. Table 2 shows Composite Reliability and Validity Statistics

Table 2: Composite Reliability and Validity Statistics

\begin{tabular}{|l|c|c|c|c|c|c|c|c|}
\hline & CR & AVE & MSV & MaxR(H) & SF & SF & MC & T \\
\hline Participation (SP) & 0.898 & 0.749 & 0.181 & 0.935 & 0.865 & & & \\
\hline System (SF) & 0.906 & 0.762 & 0.357 & 0.916 & 0.075 & 0.873 & & \\
\hline Commitment (MT) & 0.821 & 0.605 & 0.181 & 0.822 & 0.425 & -0.17 & 0.778 & \\
\hline Training (T) & 0.822 & 0.608 & 0.357 & 0.842 & 0.291 & 0.598 & 0.212 & 0.78 \\
\hline
\end{tabular}

In addition, the measure adequately satisfied the properties of discriminant validity since most of the average variance extracted (AVEs) were larger than the values of the corresponding means shared variances (MSV). Furthermore, the moderate inter-factor correlations indicated that policy compliance was a multidimensional construct consisting of distinct but interrelated dimensions. Finally, the data indicated that the composite reliability of each construct ranged between .82 (management team commitment) and .90 (system and facilities). 
Gender-Invariant Measure of Policy Compliance Practices

Another objective of this study with reference Kline, R.B. [31] was to examine the structural invariance of the instrument across one likely moderator, that is gender. To test gender-invariant, a simultaneous analysis on both the male $(\mathrm{n} 1=139)$ and female $(\mathrm{n} 2=111)$ samples was conducted, first without constraining the structural paths; the results derived a baseline Chi-square value. Next, all loadings were fixed to be identical for the male and female groups. The analysis of this constrained measure produced another Chi-square value, which was then tested against the baseline value for statistically significant differences. Table 3 shows Results of Gender-Invariant Analysis.

Table 3: Results of Gender-Invariant Analysis

\begin{tabular}{|l|r|r|r|r|}
\hline & Chi-Sq & df & \multicolumn{1}{c|}{ CFI } & \multicolumn{1}{c|}{ RMSEA } \\
\hline Unconstrained & 205 & 96 & 0.94 & 0.068 \\
\hline Constrained & 217 & 104 & 0.937 & 0.066 \\
\hline Change & 12 & 8 & -0.003 & -0.002 \\
\hline
\end{tabular}

The results of the multiple-group CFA are presented in Table 3. The invariance test across the male and female groups resulted in a statistically insignificant change in the Chi-square value, $\chi^{2}(8)=12, p>.005$. Simply said, the difference in the Chi-square values between the unrestricted model and the constrained model did not produce a poorer fit model. The path coefficients did not vary significantly across gender. It is justifiable therefore to conclude that gender did not interact with the observed variables to influence the employees' responses to the questionnaire items, and hence, gender is not a moderating variable. In sum, the 4-component solution of employees' feedback on policy compliance practices is equally applicable for male and female employees.

\section{CONCLUSIONS}

This paper presents significant contribution for business leaders especially line managers, to prudently manage compliance among employees across the board. Based on this study, it can be concluded; firstly, there is no evidence in existing research addressing these 4 dimensions namely, employees' self-participation, adequate system and facilities, management's commitment and training relative to employees' compliance in an organisation. Indeed, this compliance instrument is solidly reliable and valid to guide business leaders to manage employees' compliance at the same time genuinely shaping the compliance culture of an organisation. This is because, diligent practicing of compliance by employees is crucial and, equally important, drives an organisation to meet requirements of applicable laws and regulations. According to González, L., \& Ruggia, R. [32], compliance business experts are responsible for the business-related aspects of compliance management. In particular, they are aware of the applicable regulations, how these regulations impact on interorganizational interactions carry out through the platform and what actions (e.g. sanctions) should be taken in case these regulations are not met

The business leader may confidently use this compliance instrument as there is no gender bias in executing compliance and reassure their compliance efforts continuously. Secondly, this study impresses upon business leaders that practising compliance is not solely dependent on employees' self-participation to function efficiency but is effective collectively on account of various underlying factors as explained in the findings, regardless of all circumstances. Later, this research will be extended in two key areas:

Firstly, the self-efficacy of an employee to practice compliance at his/her workplace. Further research in this area is needed to understand the physiological, cultural and social factors in terms of challenges and barriers in compliance.

Secondly, the applicability of this compliance instrument can be further tested by conducting studies with of employees with different views in diverse industries and countries. Thus, additional dimensions, namely, auditing practices, may be included in the compliance instrument.

\section{REFERENCES}

[1] Arias, A. (2015). Understanding and managing compliance in the nature conservation context. Journal of environmental management, 153, 134-143.

[2] Ryzhakina, T., Koroleva, N., \& Makasheva, N. (2016). A process-based approach to management of the enterprise. In SHS Web of Conferences (Vol. 28, p. 01088). EDP Sciences.

[3] Quinn, R. E., \& Rohrbaugh, J. (1983). A spatial model of effectiveness criteria: Towards a competing values approach to organizational analysis. Management science, 29(3), 363-377.

[4] Nda, M. M., \& Fard, R. Y. (2013). The impact of employee training and development on employee productivity. Global journal of commerce and management perspective, 2(6), 91-93.

[5] Neyestani, B., \& Juanzon, J. B. P. (2017). ISO 9001 Standard and Organization's Performance: A Literature Review.-Int. J. Adv. Multidiscip. Res, , 4(2).

[6] Pambreni, Y., Khatibi, A., Azam, S., \& Tham, J. (2019). The influence of total quality management toward organization performance. Management Science Letters, 9(9), 1397-1406. 
[7] Alexander, A., Kumar, M., \& Walker, H. (2018), 'A Decision Theory Perspective on Complexity in Performance Measurement and Management.' International Journey of Operation and Production Management; Vol.39, No.11, p 2214-2244.

[8] Pal, K., \& Bansal, H. (2011). Management Concepts and Organizational Behaviour.

[9] Terlaak, A., \& King, A. A. (2006). The effect of certification with the ISO 9000 Quality Management Standard: A signaling approach. Journal of economic behavior \& organization, 60(4), 579-602.

[10] El Kharbili, M., Stein, S., \& Pulvermüller, E. (2008) Policy-Based Semantic Compliance Checking for Business Process Management. In MobIS Workshops (Vol. 420, pp. 178-192).

[11] Analoui, F., \& Kakabadse, A. (1992). Unconventional practices at work: insight and analysis through participant observation. Journal of Managerial Psychology.

[12] Fritz, J. (2014). Organizational misbehavior. Bullying in the workplace: Causes, symptoms, and remedies, 3-16.

[13] Geddes, B. H. (2017). Integrity or Compliance Based Ethics: Which Is Better for Today's Business?. Open Journal of Business and Management, 5(3), 420-429.

[14] Agyei-Mensah, B. K. (2017). The relationship between corporate governance, corruption and forward-looking information disclosure: a comparative study. Corporate Governance: The International Journal of Business in Society.

[15] Arena, M., \& Azzone, G. (2009). Identifying organizational drivers of internal audit effectiveness. International Journal of Auditing, 13(1), 43-60.

[16] Kibalirwandi, M. M., Akena, D. H., \& Mwesigye, A. R. (2018). Employees' policy implementation compliance scale (epic) on quality assurance policy in institutions of higher education. Art Human Open Acc J, 2(6), 407-414.

[17] Bacud, S. A. D. (2020). HENRI FAYOL'S PRINCIPLES OF MANAGEMENT AND ITS EFFECT TO ORGANIZATIONAL LEADERSHIP AND GOVERNANCE. Journal of Critical Reviews, 7(11), 162-167.

[18] Bonau, S. (2018). Drivers of Employee Commitment: Evidence from the 2011 Workplace Employment Relations Survey of Employees. International Journal of Employment Studies, 26(1), 40-61.
[19] Bonau, S. (2019). Strategic Leadership, Commitment and Employee Motivation: what influences attitudes towards the workplace. Köz-gazdaság-Review of Economic Theory and Policy, 14(4).

[20] Drucker, P. F. (1971). Drucker on management. Management Publications.

[21] Javed, S. (2015). Impact of top management commitment on quality management. International Journal of Scientific and Research Publications, 5(8), 2250-3153.

[22] Cederquist, J. G., Corin, R., Dekker, M. A., Etalle, S., den Hartog, J. I., \& Lenzini, G. (2007). Audit-based compliance control. International Journal of Information Security, 6(2-3), 133-151.

[23] Davis, R. C. (1958). A philosophy of management. Academy of Management Journal, 1(3), 37-40.

[24] Diamantidis, A. D., \& Chatzoglou, P. D. (2014). Employee post-training behaviour and performance: evaluating the results of the training process. International Journal of Training and Development, 18(3), 149-170.

[25] Susomrith, P., Coetzer, A., \& Ampofo, E. (2019). Training and development in small professional services firms. European Journal of Training and Development.

[26] Taylor, F. W. (2004). Scientific management. Routledge.

[27] Crede, M., \& Harms, P. (2019). Questionable research practices when using confirmatory factor analysis. Journal of Managerial Psychology.

[28] Brown, T. A. (2015). Confirmatory factor analysis for applied research. Guilford publications.

[29] Byrne, B. M. (2010). Structural equation model with AMOS: Basic concepts, applications, and programming (2nd ed.). New York, NY: Taylor \& Fancis Group.

[30] Wu, A. D., Zhen, L., \& Zumbo, B. D. (2007). Decoding the meaning of factorial invariance and updating the practice of multi-group confirmatory factor analysis: A demonstration with TIMSS data. Practical Assessment, Research, and Evaluation, 12(1), 3.

[31] Kline, R.B. (2016). Principles and practice of structural equation modeling (4th ed.). NY: The Guilford Press.

[32] González, L., \& Ruggia, R. (2018). A Comprehensive Approach to Compliance Management in Interorganizational Service Integration Platforms. In ICSOFT (pp. 722-730). 